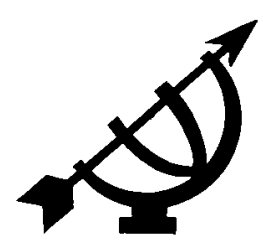

\title{
Die voorstelling van VIGS-verwante stigma in 'n versameling gedigte deur Afrikaanssprekende hoërskoolleerders
}

\author{
Adelia Carstens \\ Eenheid vir die Ontwikkeling van Taalvaardigheid \\ Universiteit van Pretoria \\ PRETORIA
}

E-pos: adelia.carstens@up.ac.za

\begin{abstract}
The representation of AIDS-related stigma in a collection of poems by Afrikaans-speaking teenagers

This article reports on a discourse analysis of twenty-two poems written by a group of white South African teenagers, with special reference to the construal of people living with HIVIAIDS and the role that stigmatisation plays. The vantage point is that of Christian ethics, while psycho-social models of stigma, and the archetypes of people living with HIVIAIDS (as portrayed by the media) serve as the descriptive framework. The most salient stigma-enhancing factor was found to be the perception that self-stigmatisation is an undeniable reaction to the disease. Although coming to terms with one's HIV status by finding a deeper meaning in the disease can be regarded as a stigma-reducing response, it may be harmful if personal responsibility for one's physical and mental well-being is not acknowledged and exercised. The article concludes with a number of recommendations regarding destigmatising intervention messages based on ethical principles.
\end{abstract}

Opsomming

Die voorstelling van VIGSverwante stigma in ' $n$ versameling gedigte deur Afrikaanssprekende hoërskoolleerders

Hierdie artikel lewer verslag oor 'n diskoersanalise van twee-en-twintig gedigte deur 'n groep wit Suid-Afrikaanse tieners, met spesifieke verwysing na die voorstelling van mense met MIVIVIGS en die rol wat stigmatisering daarin speel. Die Christelike etiek dien as vertrekpunt, terwyl psigososiale modelle oor stigma en die argetipes van mense wat met MIVIVIGS saamleef (soos deur die nuusmedia uitgebeeld) as 
deskriptiewe raamwerk geld. Die belangrikste stigmaversterkende faktor het geblyk te wees die persepsie dat selfstigmatisering 'n onontwykbare reaksie op die siekte is. Hoewel aanvaarding van jou MIV-status deur die soeke na 'n dieper betekenis in die siekte as 'n stigmareduserende respons beskou kan word, mag dit skadelik wees indien dit daartoe lei dat persoonlike verantwoordelikheid vir geestelike en fisieke welsyn nie aanvaar word nie. Die artikel sluit af met 'n aantal voorstelle vir die ontwerp van destigmatiserende intervensieboodskappe wat op 'n etiese grondslag berus.

\section{Inleiding}

Hierdie artikel lewer verslag oor 'n diskoersanalise van twee-entwintig gedigte deur 'n groep wit Suid-Afrikaanse tieners, met spesifieke verwysing na die voorstelling van mense met MIVIVIGS en die rol wat stigmatisering in hierdie voorstelling speel. Die Christelike etiek dien as vertrekpunt, terwyl psigososiale modelle oor stigma en die argetipes van mense wat met MIV/VIGS saamleef (soos deur die nuusmedia uitgebeeld) as deskriptiewe raamwerk geld. Aangesien die navorsingsontwerp kwalitatief is, was die oogmerk om insig te verkry in die denkprosesse van die tieners oor die onderwerp, eerder as om veralgemenings te probeer maak. Die destigmatiseringsboodskappe wat in die slotsom geïdentifiseer word, is dus voorlopig en sal aan voortoetsing onderwerp moet word voordat hulle in destigmatiseringsveldtogte gebruik kan word.

\section{Agtergrond en denkraamwerk}

Die term "stigma" verwys na enige kenmerk wat die draer daarvan identifiseer as sosiaal onaanvaarbaar of minderwaardig en waardeur die gestigmatiseerde persoon op een of ander wyse benadeel word (Paterson, s.j.; Herek, 2002:595; Dovidio, Major \& Crocker, 2000:1). Stigmatisering is ' $n$ baie algemene reaksie op siekte. Deur die loop van die geskiedenis is bepaalde siektes deur die mensdom gestigmatiseer, byvoorbeeld melaatsheid, tuberkulose, geestesiektes, asook seksueel oordraagbare siektes. MIVIVIGS is die jongste toevoeging tot hierdie lys (Brown, Trujillo \& Macintyre, 2001:15). Die rede waarom bepaalde siektes gestigmatiseer word en ander nie, hou verband met sosiale en kulturele oortuigings oor persoonlike skuld/sonde, oortuigings oor die invloed van bose magte, (vermeende) oortreding van gemeenskapsnorme, geneesbaarheid (al dan nie) en aansteeklikheid. MIVIVIGS is reeds (in verskillende kulture) met al hierdie kenmerke in verband gebring.

Aan die einde van 1999 was daar ongeveer 2300000 kinders in Suid-Afrika wat met MIV besmet was (Pocock, 2003:25) en volgens 
LoveLife (2000) kom ongeveer 60\% van alle nuwe infeksies in SuidAfrika binne die ouderdomsgroep 15-25 voor. Stigmatisering is ook reeds onder jongmense ' $n$ groot probleem waarmee rekening gehou moet word. 'n Nuusberig in MSN se aanlyn-nuusblad (2004) beklemtoon byvoorbeeld kinders se vrees om as MIV-positief geïdentifiseer te word. Een MIV-positiewe leerder het die verslaggewer meegedeel dat "any person with the virus is the cause of gossip and almost everyone develops a curiosity to get a glimpse of the victim once he or she has reached the terminal stage", terwyl 'n ander daarvan oortuig was dat "if my schoolfriends knew, they would say 'You will die soon'. That would make me feel bad." (MSNBC News, 2004).

Stigmatisering en destigmatisering binne die kader van MIVIVIGS kan vanuit verskillende teoretiese en filosofiese perspektiewe benader word: 'n Regskundige perspektief beklemtoon menseregteskendings (Jennings et al., 2002) en word onderlê deur norme soos "gelykheid". Binne 'n biomediese en epidemiologiese perspektief word stigmatisering beskou as een van die grootste struikelblokke in die weg van beheer en bestuur van die epidemie (Aggleton \& Parker, 2002:5), omdat dit indruis teen die norm van "'n kwaliteitlewe". Stigmatisering laat mense daarvan wegskram om hulle serostatus bekend te maak en die pasiënt ontvang gevolglik nie behandeling en berading wat sy/haar lewenskwaliteit kan verhoog nie. 'n Antropologiese invalshoek fokus op die gebruike, norme en waardes waardeur gemeenskappe in stand gehou word, en "onderlinge verantwoordelikheid" geld as 'n grondbeginsel of waarde. Hierdie waarde kan egter in bepaalde omstandighede tot nadeel van die individu strek. Die gestigmatiseerde kondisie (byvoorbeeld MIV/VIGS) word in bepaalde kulture as verdiende straf beskou op die individu se oortreding van gemeenskapsnorme; of as 'n ramp wat spruit uit 'n kwaadwillige persoon (heks, towenaar, ensovoorts) se manipulasie van sekere magte (Jennings et al., 2002; Van Dyk, 2001).

In die kognitiewe en sosiale sielkunde word gefokus op sowel die houdings, oortuigings, waardes en gedragsintensies wat gestalte gee aan stigmatisering (van andere én die self), as op die reaksies op stigmatisering. Vanuit 'n kognitief-affektiewe perspektief is die proses van stigmatisering soos volg gestruktureer (Aggleton \& Parker, 2001; Brown et al., 2001; Herek et al., 2002; Herek \& Capitanio, 1999; Parker \& Aggleton, 2002; UNAIDS, 2002):

- Die proses is veranker in individue se waarde- en oortuigingstelsels - in hierdie geval hulle oortuigings oor VIGS as 
'n siekte, die oorsake van die siekte, hoe dit versprei word, oor mense wat met MIVIVIGS saamleef en oor die sosiale groepe waarmee hulle geassosieer word (byvoorbeeld intraveneusedwelmgebruikers, homoseksuele en biseksuele mans, prostitute, swart mense, ensovoorts). Hierdie stelsels van waardes en oortuigings word geïnternaliseer en versterk deur openbare diskoerse.

- Die oortuigings stimuleer op hulle beurt emosies soos woede en veragting teenoor dié wat as "afwykend" van die (gesonde) norm beskou word, asook vrees om die siekte op te doen.

- Die oortuigings en emosies gee ook aanleiding tot houdings soos vooroordeel (op basis van groeplidmaatskap) en skuld (wat weer veranker is in religieuse of morele oortuigings en waardes).

- Houdings van vooroordeel kan eerstens lei tot diskriminerende gedrag by stigmatiseerders, byvoorbeeld aantasting van die regte van die gestigmatiseerde persoon en/of diegene wat met hom/ haar geassosieer word, en verwerping van die gesin of familie; en dit kan ook lei tot vermydende of ander negatiewe gedrag deur die gestigmatiseerde persoon.

Vanuit 'n gemeenskapsperspektief kan onderskei word tussen "stigmatiseerders" (diegene wat stigmatisering "pleeg" en wat vermoedelik MIV-negatief is, asook groepe en instellings wat voorgee om namens die "gesonde" deel van die gemeenskap op te tree) en "gestigmatiseerdes" (dié wat regstreeks of onregstreeks deur die stigma benadeel word). "Stigmatiseerders" reageer op mense met MIV/VIGS deur emosies soos woede, waaruit gedragsresponse soos die weiering van ondersteuning, mishandeling (fisiese geweld of selfs moord), skending van menseregte en sosiale verwerping deur die gemeenskap mag spruit. Op die institusionele vlak kan stigmatisering aangeblaas word deur wetgewing wat daarop gerig is om die optrede van individue/groepe wat met MIV besmet is, te beheer (Aggleton, 2000). Op gemeenskapsvlak het diskriminerende praktyke al dikwels in die verlede tot uiting gekom in handelinge soos segregasie in skole en hospitale, vernederende behandeling in gevangenisse, onregverdige afdanking, weiering tot aanstelling, miskenning van die reg om te trou, MIV-toetsing as voorvereiste en die weerhouding van gesondheidsdienste (Aggleton \& Parker, 2002:11-12).

Potensiële stigmatiseerders (sero-negatiewe mense) kan egter ook positief of teen-stigmatiserend optree deur hulp te verleen aan dié wat primêr of sekondêr deur die siekte geraak word. In die 
georganiseerde openbare lewe kan MIV/VIGS-verwante stigma gehanteer word deur middel van verskeie strategieë en intervensies wat gerig is op spesifieke kontekste, soos individue, gesinne, gemeenskappe en instellings (Aggleton, 2001; Aggleton \& Parker, 2002; Brown et al., 2001; Jennings et al., 2002). Een van die doelwitte met analises soos dié waaroor hier verslag gedoen word, is juis om 'n bydrae te lewer tot 'n positiewe eksterne respons wat as deel van 'n intervensieveldtog neerslag kan vind in die opvoedkundige sektor.

"Gestigmatiseerdes" reageer dikwels negatief op diskriminasie deur dit te internaliseer. In die literatuur word daar soms onderskei tussen "psigologies ervaarde" en "fisiek ervaarde" stigma (Aggleton, 2000; Brown et al., 2001:4; Jacoby, 1994). Psigologies ervaarde stigma is die werklike of denkbeeldige vrees vir negatiewe houdings van en diskriminasie deur die gemeenskap. Dit gee aanleiding tot selfstigmatisering, wat manifesteer in gevoelens van waardeloosheid, wanhoop en vrees (vir isolasie, fisiese aftakeling en die dood). Die NIMH Research Workshop (1996) onderskei verder tussen "primêre" en "sekondêre" stigma, oftewel stigma wat beleef word deur primêre en sekondêre teikens. Primêre teikens is mense wat (vermoedelik) MIV-positief is. Sekondêre teikens sluit metgeselle, gesinslede en geliefdes van mense met MIV in, asook gesondheidswerkers wat diens aan hulle lewer, of diegene wat as kampvegters vir mense met MIV optree. Fisiek ervaarde stigma verwys na die werklike ervaring van diskriminasie deur die optrede van stigmatiseerders, byvoorbeeld fisieke geweld, weiering tot aanstelling, weiering van gesondheidsvoordele of fisieke verwerping deur die gemeenskap. Positiewe reaksie op 'n gestigmatiseerde identiteit staan in die psigologie-literatuur as "stigmabeheer" bekend (Stanley, 1999). Stigmabeheer word bereik deur probleemoplossende houdings en gedrag, soos byvoorbeeld om verantwoordelikheid te aanvaar vir sowel 'n mens se fisieke gesondheid as sy geestesgesondheid. Fisieke gesondheid kan verbeter of in stand gehou word deur gereelde oefening, gesonde eetgewoontes en nakoming van medisyneprotokolle, terwyl geestesgesondheid verbeter kan word deur die ontwikkeling van 'n positiewe selfdiskoers, vergeesteliking van die betekenis van die siekte in 'n mens se lewe (Stanley, 1999:106), bekendmaking van 'n mens se status, deelname aan identiteitspolitiek en optrede as voorspraakmaker vir die regte van mense met MIV.

Teenoor denkraamwerke soos dié van die kognitiewe en sosiale sielkunde, wat stigmatisering hoofsaaklik vanuit 'n etiologiese en probleemgerigte perspektief benader, fokus die Christelik-etiese be- 
nadering op beginsels wat as rigtinggewende norme geld en wat nie as reaksie op ' $n$ probleem ingespan word nie. Pocock (2003:38) identifiseer in hierdie verband die volgende vier beginsels:

- Respek vir die outonomie van ander

- Goed doen (beneficience), wat impliseer

- Nie leed aandoen nie (non-maleficience)

- Geregtigheid

Respek vir die outonomie van ander verwys na die vermoë om selfstandig te dink, te besluit en onafhanklik op te tree. Om hulle outonomie uit te oefen, het mense inligting en ondersteuning nodig waarop hulle hul besluite kan grond, maar ook 'n mate van vryheid, sodat hulle besluite kan neem sonder onregmatige druk of manipulasie.

Goed doen (beneficience) en nie leed aandoen nie (nonmaleficience) sluit regstreeks by die liefdesgebod aan. Volgens hierdie gebod is elkeen verplig om sy/haar naaste lief te hê soos hom-/haarself (Matt. 22: 39; Mark. 12:31; Luk. 10:25-28; vgl. ook Kavar, 1988:10; Pocock, 2003:40). Die mens is verplig om na die welstand van andere om te sien en hulle nie skade aan te doen nie (vgl. die Eed van Hippokrates). Ingevolge die beginsels van goed doen en nie leed aandoen nie, moet die Christen op stigma reageer deur ondersteuning te bied aan dié wat daardeur geraak word - ook aan diegene wat deur lede van die eie groep (byvoorbeeld ander Christene) gestigmatiseer word. Jesus se optrede op aarde dien as voorbeeld van aktiewe destigmatisering: Hy eet saam met veragte belastinggaarders (Mark. 2:15) en raak uitgeworpe melaatses aan om hulle te genees (Luk. 5:12-16). Die gelykenis van die Barmhartige Samaritaan (Luk. 11:25-37) beklemtoon dieselfde boodskap. Net soos stigmatisering van ander deur die Christelike lewensbeskouing afgekeur word (volgens die beginsel van goed doen en nie leed aandoen nie), word ook die internalisering van stigma (selfstigmatisering) hierdeur afgekeur. Elke mens is verantwoordelik vir die instandhouding van sy/haar liggaamlike en geestesgesondheid (1 Kor. 6:19).

God is 'n God van geregtigheid. Hy het alle mense na sy beeld geskep en elkeen het intrinsieke waarde voor Hom (Gen.1:26). Alle mense is dus gelykwaardig. Verskille in status, geslag, vermoëns of meriete regverdig nie diskriminasie nie. Daar is 'n lang tradisie in die Westerse wêreld om siekte te verbind met God se straf op sondige dade (Jennings et al., 2002) en binne hierdie tradisie word mense met MIV/VIGS as skuldig en blaamwaardig beskou op grond 
daarvan dat hulle 'n morele sonde begaan het. Siekte is egter, volgens die Christelike beskouing, nie 'n straf op sonde nie. God betaal die mens nie terug vir sy/haar oortredinge nie, want Hy is 'n liefdevolle God (Ps. 103:8-18). God diskrimineer ook nie teen bepaalde sosiale groepe deur siekte nie. Naäman, 'n invloedryke en belangrike man, is byvoorbeeld nie die siekte van melaatsheid gespaar nie (2 Kon. 5).

Hoewel die Christelik-etiese filosofie fokus op beginsels wat positiewe response op vraagstukke fasiliteer, kan dilemmas binne die kader van MIVIVIGS ontstaan deurdat etiese en morele beginsels soms strydig met mekaar is. Dit is moontlik dat die etiese beginsel van "gelykheid" kan bots met 'n morele waarde soos "'n rein lewe". Daar sou onder andere gevra kon word of mense wat 'n immorele lewe ly nie tog ook reg op gelyke behandeling en lewenskwaliteit het nie?

Ten einde die aard en omvang van tieners se positiewe en negatiewe reaksies op gestigmatiseerde identiteite te ondersoek, moet 'n aantal vrae gevra word: deur watter denkraamwerke of diskoerse word tieners se konstruksie van mense met MIVIVIGS beïnvloed? Watter rol speel die media, soos koerante, TV en ander massamediaprodukte? In watter mate is hierdie diskoerse strydig of versoenbaar met etiese reaksies op stigma wat in die skool en kerk onderrig word? Die uitgangspunt van die Christelike kerk is alreeds kortliks uiteengesit. Vervolgens word 'n oorsig gegee oor die mediavoorstelling van mense met MIV/VIGS.

\section{Representasie van MIV/VIGS in die media}

Die voorstelling van mense met MIV/VIGS op TV, oor die radio en in die gedrukte media is "gemedieerde" diskoerse. Die media bied aan hulle lesers en gehore 'n weergawe van die werklikheid, soos gesien deur die bril van byvoorbeeld politici, ekonome, filosowe, teoloë en opvoedkundiges. Hierdie werklikheidsperspektief word deur die joernalis verder "vertaal" na die ideologie van die betrokke nuusinstansie en verpak in 'n formaat wat die instandhouding van bepaalde hegemonieë fasiliteer. So is vroeë diskoerse oor VIGS as 'n siekte gekenmerk deur 'n reeks kragtige metafore wat daartoe gedien het om stigmatisering te versterk en te legitimeer. Hierdie metafore sluit onder andere die volgende in: MIVIVIGS as die dood (deur afbeeldings soos dié van die "insamelaar van die oes" of 'n skedel), as 'n kriminele oortreding, as oorlog, as 'n monster, 'n slang en as andersheid (Stein, 2003). In lande met skaars hulpbronne pas dit om mense met MIV/VIGS voor te stel as terminaal siek en 
onbehandelbaar (vigsslagoffers) en om sondebokke uit te wys wat vir die oordrag van die siekte verantwoordelik is (vigsdraers).

In die internasionale media was uitbeeldings van mense met MIV as "vigsslagoffers" oorheersend tot en met die middel van die negentigerjare. Crimp (1992:118) beskryf die prototipiese uitbeelding van die vigsslagoffer as "ravaged, disfigured and debilitated by the syndrome [...], generally alone, desperate and 'resigned' to their inevitable death".

Sporadies het rapportering oor die "vigsdraer" begin toeneem. Homoseksuele mans, intraveneusedwelmgebruikers en biseksuele mans het algaande meer prominent in die internasionale media begin figureer. Koerantberigte het hierdie individue voorgestel as onbeheersd, gevaarlik en gewelddadig, byvoorbeeld dwelmverslaafdes wat mense met spuitnaalde aanval of byt, of wat hulle spuitnaalde laat rondlê waar "onskuldige" mense daardeur besmet kon raak (Lupton, 1999:46). In ander mediavoorstellings word mense met MIV/VIGS weer uitgebeeld as booswigte, wat slinksberekend daarop uit is om andere leed aan te doen. Hierdie persone sou veral uit wraak en bitterheid optree, omdat hulle self MIV-positief is. Nog 'n tipe vigsdraer wat deur die media gekonstrueer is, is die persoon wat die virus versprei deur onbeskermde seks. Hierdie persone word uitgebeeld as 'n bedreiging vir ander, nie omdat hulle wraaksugtig is nie, maar weens hulle losse morele waardes en ' $n$ gebrek aan seksuele selfbeheersing (Juhasz, 1990; Sacks, 1996). Hoewel dit nie soveel internasionale blootstelling in die media ontvang het nie, het die MIV-positiewe ma wat die siekte aan haar ongebore baba ('n slagoffer) oorgedra het deur geboorte of borsvoeding ook algaande prominenter begin raak.

Gedurende die tweede helfte van die negentigerjare het die "vigsoorwinnaar"-argetipe meer prominent in die media begin figureer (Lupton, 1999:44). Dit is die MIV-positiewe persoon wat verantwoordelikheid aanvaar vir sy/haar fisieke en geestesgesondheid en wat as rolmodel, voorspraakmaker of aktivis optree (Lupton, 1999). Mense wat met MIV/VIGS saamleef, wat oor jare heen gesond gebly het sonder merkbare immuundisfunksie, het in die nuusmedia prominent begin word. Klem is toenemend geplaas op individue se positiewe emosionele en psigologiese reaksie op hulle siektetoestand, asook op hulle selfsorgroetines om die simptome van MIVIVIGS onder beheer te hou. Die rede waarom 'n meer etiese respons op stigmatisering van sero-positiewe mense eers in die negentigerjare na vore gekom het, moet waarskynlik toegeskryf word aan die toenemende bemoeienis van kerklike en ander 
gemeenskapsgerigte organisasies, asook die voorspraakaktiwiteite van prominente persone.

In Suid-Afrika het mediaverslaggewing die internasionale patroon grootliks weerspieël. Analises van rapportering oor MIV/VIGS in hoofstroom- Suid-Afrikaanse koerante deur Gevisser (1995) en Stein (2001) toon aan dat plaaslike dekking tot die middelnegentigerjare gedomineer is deur die stereotipe van die vigsslagoffer, spesifiek dié wat aan VIGS gesterf het. Beelde van uitgeteerde mense, na wie dikwels verwys is as "slagoffers van vigs" of "vigslyers", was prominent in die meeste koerante. Die klem het dikwels geval op simptome, soos die uitskei van liggaamsvloeistowwe en die gevaar dat versorgers besmet kon raak wanneer hulle omsien na baie siek pasiënte.

Die vigsdraer-argetipe is aanvanklik hoofsaaklik deur homoseksuele mans verteenwoordig, maar sedert die negentigerjare is hierdie representasies stadigaan vervang deur dié van VIGS as 'n siekte wat besig is om onder swart heteroseksuele persone te "ontplof" (Gevisser, 1995).

In die Suid-Afrikaanse media is daar tot en met die aanbreek van die nuwe millennium slegs sporadies na vigsoorwinnaars verwys. Dit is eers ná 2000 dat hierdie argetipe meer prominent in die SuidAfrikaanse media begin word het, hoofsaaklik as gevolg van bewusmakingsveldtogte deur 'n handjievol MIV-positiewe individue, soos die twaalfjarige Nkosi Johnson (wat in Junie 2001 gesterf het), regter Edwin Cameron (wat sy serostatus gedurende die laat negentigerjare openbaar gemaak het) en die Treatment Action Campaign-aktivis, Zachie Achmat, wat geweier het om antiretrovirale middels te gebruik totdat die Regering die groen lig gegee het vir die invoer van bekostigbare generiese middels. Van Januarie 2000 tot Desember 2002 het meer as 40 nuusberigte oor die lewe en optrede van Nkosi Johnson in die Afrikaanse dagblad, Beeld, verskyn en twaalf in die Afrikaanse Sondagkoerant, Rapport. Vyf-envyftig berigte in Beeld noem regter Edwin Cameron se naam in verband met sy MIV-status en sy agitering vir die gratis beskikbaarstelling van antiretrovirale middels aan MIV-positiewe mense (News24.com, 2003). Hierdie publisiteit wat verleen is aan individue wat as voorspraak begin optree het vir MIV-positiewe persone, kan gedeeltelik toegeskryf word aan die feit dat spesifieke joernaliste aan vigsverslaggewing toegewys is en dat die media toenemend bewus geword het van sy opvoedkundige taak. 


\section{Metodologie}

Die databasis wat vir die diskoersanalise van die vigsgedigte gebruik is, bestaan uit twee-en-twintig gedigte deur Afrikaanssprekende leerders tussen die ouderdomme van 14 en 17 jaar (graad 8 tot 11). Hierdie gedigte is in 2002 ingeskryf vir die landswye Afrikaans Ekspo vir hoërskoolleerders wat jaarliks deur die Stigting vir die Bemagtiging van Afrikaans georganiseer word.

Die keuse het op gedigte as eenhede van analise geval, omdat algemeen aanvaar word dat poësie die diepste kognisies en emosies van outeurs verwoord (Goleman, 1996:54).

Die gebruikmaking van 'n gerieflike (convenient) steekproef waarin al die respondente hulleself as't ware self "geselekteer" het, sou deur navorsingsmetodoloë (kyk Babbie \& Mouton, 2002; Strydom \& Venter, 2002:207) as riskant beskou kon word. Tog kan die keuse van hierdie metode verdedig word op grond daarvan dat dit minder bedreigend is as byvoorbeeld persoonlike onderhoude. Hierdie seleksiemetode lewer ook waarskynlik minder "sosiale verwagtingseffekte" op as metodes waarin respondente direk gekonfronteer word.

Die navorsingsmetode is kwalitatief en bevat elemente van sowel deduksie as induksie. Deduksie is ter sprake deurdat daar bewustelik gesoek is na instansiërings van die drie argetipes wat hierbo geïdentifiseer is. Die detailanalise was egter induktief, deurdat subkategorieë en hulle definiërende kenmerke op die basis van kritiese lees en voortdurende vergelyking (constant comparison) geïdentifiseer is.

\section{Analise van die data}

\subsection{Die "slagoffer"-argetipe}

Gestigmatiseerdes se negatiewe response op stigma word deur twee argetipes verteenwoordig, naamlik dié van die vigsslagoffer en dié van die vigsdraer. Die betrokke korpus word veral deur die slagoffer-argetipe gedomineer. Die fokus in die gedigte is egter nie soseer op die swakker wordende, bedgekluisterde pasiënt wat van versorgers afhanklik is nie. Slegs drie gedigte verbeeld die fisieke effekte van 'n immuunsisteem wat besig is om in te gee, soos byvoorbeeld koors, gewigsverlies, velinfeksies en lugweginfeksies (gedigte 3, 4 en 8). Fisiek ervaarde selfstigmatisering word egter genuanseerd in die gedigte gekonstrueer. Elf gedigte bevat verwysings na die geïnternaliseerde ervaring van stigma, met 
gevolglike selfdestruktiewe en antisosiale gedrag. Die konsepgroepe wat prominent figureer verteenwoordig gevoelens van magteloosheid en wanhoop $(1,3,4,5,15)$, hartseer $(1,15,20,21)$ en angs/ vrees $(3.9,11,18,21)$.

Die angs/vrees wat verbeeld word, hou egter disproporsioneel verband met die representasie in die media. Die woord dood en sy fleksievorme, afleidings, samestellings en sinonieme verskyn nie minder nie as vyftien keer in die gedigte. Daarbenewens is daar tien verwysings na lewensverlies as gevolg van VIGS. 'n Moontlike verklaring vir die prominensie wat aan die dood verleen word, is te vinde in die werk van Marshall en O'Keefe (1994:75), wat ondersoek gedoen het na die ooreenkomste tussen mediese studente se sekondêre (gerapporteerde) narratiewe en die primêre narratief van 'n persoon met MIV/VIGS. Die mediese studente se grafiese verwoording van die pasiënt se vrees om alleen gelaat te word en 'n pynlike, liefdelose dood te sterf, was strydig met die pasiënt se werklike verwysings na die dood - wat in werklikheid redelik beperk was.

Afgesien van die vrees vir die dood in die hoërskoolleerders se lekenarratiewe, blyk dit dat hulle ook die intensiteit van selfstigmatiserende emosies oordryf. Hiervan getuig die oorleksikalisering $^{1}$ van wanhoop, magteloosheid, hartseer en sosiale isolasie:

En somtyds as sy lag, is haar oë dié van 'n mishandelde kind (gedig 1).

Die smart brand binne my (gedig 20).

Metafore soos "My dae is hel" en "My nagte is swart" dui op 'n hiperboliese rekonstruksie van die medianarratiewe. Die oorvloedige verwysings na diepe hartseer en isolasie staan ook in teenstelling met die afwesigheid van beskrywings van hierdie emosie in die nuusmedia.

'n Moontlike verklaring vir hierdie oordrywing van vrees, hartseer en depressie mag 'n lewensfase-gebonde konstruksie van betekenis wees: mense van verskillende ouderdomsgroepe het verskillende mentale skemata vir die onderskeie stadia van 'n mens se lewe,

$1 \quad$ Fairclough (1992:193) gebruik die term overwording (in navolging van Halliday 1978, wat die term overlexicalization gebruik) om te verwys na die relatiewe digtheid van die leksikale items uit 'n bepaalde domein, wat 'n teken is van "intense preoccupation, pointing to peculiarities in the ideology of the group responsible for it". 
naamlik geboorte, babatyd, die peuter- en kleuterstadia, die laerskool-kinderjare, tienerjare, adolessensie, jong volwassenheid, middeljare, gryse jare, ensovoorts. 'n Mens kan hipotetiseer dat die dood nie 'n datagleuf in jongmense se lewenskema vir die tienderjare verteenwoordig nie. Hierteenoor verteenwoordig sosiale isolasie, verlies aan hedonistiese plesier en voortydige dood die jongmens se grootste vrese.

Die baba wat met MIV gebore word (as subtipe van die slagofferargetipe), figureer merkwaardig dikwels in die gedigte. Vyf gedigte $(2,9,11,17,19)$ verwys na babas wat met MIV gebore word. "Slagofferskap" word eksplisiet verwoord deur onder andere van passiefkonstruksies gebruik te maak. Vergelyk gedig 2: Duisende babas word daagliks besmet. In die meeste van die gedigte word dit egter leksikaal uitgedruk deur die woord keuse:

Sy is 'n baba, en haar ma is ' $n$ vigslyer; sy het geen keuse nie (gedig17).

Die prominensie van hierdie subtipe kan moontlik ook verklaar word deur die lewensfasebeskouing wat vroeër uiteengesit is. Die beeld van 'n kind wat aan 'n terminale siekte ly en waarvan die lewensverwagting drasties verkort is, is nie met hierdie skema versoenbaar nie.

\subsection{Die "draer"-argetipe}

Drie subtipes van die draer het in die data na vore gekom, naamlik die "kwaadwillige besmetter", die "promiskue metgesel" en die "onkundige/onverskillige moeder" (wat die virus na haar ongebore baba oordra, sonder om voorsorg te probeer tref).

Die "kwaadwillige besmetter" figureer in gedig 18, waarin drie brekers by 'n partytjie aankom. Hulle demonstreer geweld en kwaadwillige motiewe, deurdat hulle eers met een van die karakters in die gedig flankeer en haar daarna ontvoer en verkrag. Daar word later bevind dat sy MIV-positief is.

In gedig 16 kom ons die "promiskue metgesel" teë, naamlik 'n MIVpositiewe meisie wat 'n naïewe jong seun verlei, wat dan na haar toe bly terugkeer vir seks. Die meisie is 'n prototipiese draer, terwyl die seun geklassifiseer kan word as 'n nie-prototipiese slagoffer (aangesien hy toegee aan wellus). Die eksplisiete afkeer aan die kwaadwillige besmetter rym met die etiese beginsel van "niekwaadwilligheid". Die negatiewe oordeel oor die promiskue metgesel is in ooreenstemming met die beginsel van "respek vir die 
outonomie van ander". Deur 'n ander persoon nie oor jou MIVpositiewe status in te lig nie, ontneem jy hom/haar die keuse om seksuele omgang te weier en besmetting te voorkom.

Hoewel die "onverskillige/traak-my-nie-agtige moeder" nie as tema van een van die gedigte figureer nie, word sy wel gekonstrueer as die bron van skuld wanneer die moeder-na-kind-oordrag-slagoffer uitgebeeld word. Gedig 11 beskuldig die moeder onomwonde, omdat sy haar baba vonnis tot "'n lewe van siekte en swaarkry". Gedig 17, getiteld "Ongewenste baba", maak ook die verhouding tussen die moeder en haar besmette kind eksplisiet deur die woorde "Dit is als haar ma se skuld". Hierdie gedig beklemtoon die onverskilligheid en onbedagsaamheid van die ma met die wanhopige uitroep "As haar ma net verstandig was, sou sy 'n kans gehad het!" Die prominensie van hierdie tipe slagoffer in die korpus kan moontlik verklaar word met verwysing na die Afrikaner se morele oortuigings omtrent monogamie en getrouheid in die huwelik. Blaamlegging is egter strydig met die etiese beginsel van geregtigheid, naamlik die oortuiging dat die oordeel die mens nie toekom nie.

\subsection{Die "oorwinnaar"-argetipe}

In ses gedigte word optimistiese teendiskoerse aangetref wat beelde oproep van die oorwinnaar-argetipe. Hoewel geeneen van die gedigte beelde van mense oproep wat redelik normaal met MIV saamleef nie - en wat dus die jongste ontwikkelinge in die mediese wetenskap ignoreer - is daar wel getuienis van 'n stadige ontwaking van die oortuiging dat 'n mens 'n lewe van gehalte kan bly voer met MIV, mits jy 'n positiewe emosionele en psigologiese lewenshouding aankweek en verantwoordelike selfsorg toepas. 'n Vigslyer kan dus 'n "vasbyter" (coper) wees. Dit begin ook op die jeug 'n indruk te maak dat welaangepaste, positiewe gedrag vir die gemeenskap tot voordeel is indien die vigsoorwinnaar as 'n "voorspraakmaker/ rolmodel" optree deur ander te inspireer.

Die oortuiging dat daar lewe ná die dood is (in hierdie geval binne 'n Christelik-religieuse paradigma), het aanleiding gegee tot 'n verdere subtipe van die oorwinnaar, naamlik die "soeker na dieper betekenis" - selfs indien dit onvermydelik is dat die liggaam tot niet gaan wanneer jy sterf, kan 'n mens uitsien na 'n siektevrye en stresvrye lewe ná die dood.

In die volgende subparagrawe word die konstruksie van elkeen van hierdie subtipes nader bekyk. 


\subsubsection{Die "vasbyter" (coper)}

Die vasbyter is 'n subtipe wat op die grens tussen die slagoffer- en die oorwinnaar-subtipes geplaas kan word. Hoewel die korpus nie getuienis lewer van prototipiese vasbyters nie, word 'n persoon se hantering van sy/haar MIV-status in bepaalde gedigte as 'n ideaal gesien waarheen gestrewe moet word. Gedig 5 stel dit dat ten spyte van pessimiste se beklemtoning van die feit dat daar steeds geen geneesmiddel vir VIGS is nie, alle mense met MIV of VIGS die reg het op goeie gesondheid. 'n Beroep word op gesonde mense gedoen om mense met MIV fisiek en emosioneel te ondersteun en "hulle harte aan te raak" - dus om die etiese beginsel van goed doen en nie leed aandoen nie, na te streef. In gedig 21 ekspliseer die digter haar navolging van hierdie beginsel deur te verklaar dat vigslyers haar nodig het en dat dit haar plig is om "teen die monster [te] veg".

Gedig 12 getuig van die internalisering van die beginsel van goed doen (ook teenoor die self) deur 'n beroep op vigslyers te doen om hulle nie te bekommer oor die lelike/slegte dinge wat ander mense oor hulle sê nie, maar om verantwoordelikheid te aanvaar vir hulle eie lewens deur gesond te eet, na hulleself om te sien en die siekte te beveg.

\subsubsection{Die "rolmodel/voorspraakmaker"}

Die vigslyer wat 'n voorspraakmaker en rolmodel word, figureer prominent in die gedigte. In plaas daarvan om in selfbejammering en hartseer te verval, gebruik die vigslyer die siekte om andere te inspireer. Hierdie subtipe demonstreer duidelik die etiese beginsel van "respek vir die outonomie van ander" deur aan ander mense inligting en ondersteuning te gee waarop hulle hul besluite kan grond, maar ook die vryheid om besluite te neem sonder onregmatige druk of manipulasie. Twee gedigte (6 en 22) is volledig gewy aan die twaalfjarige tiener, Nkosi Johnson, wat in Junie 2001 oorlede is. Hierdie gedigte het 'n sterk epiese inslag. Hulle besing die lof van hierdie jong seun wat 'n held geword het. Gedig 6 sê dat hy ons deur sy liefde geleer het hoe om te lewe, al was hy self besig om te sterf. Dit, sê die gedig, het hy bereik deur "sy seëninge te tel" en deur vasberadenheid. In die oë van die jong digter is hy ' $n$ "oorwinnaar" ten spyte van sy uiteindelike dood. Die voorstelling van 'n vigsaktivis soos Nkosi as 'n held en 'n oorwinnaar, is vergelykbaar met die positiewe voorstelling van die Amerikaanse basketbalspeler, Magic Johnson, wat in sowel die Amerikaanse as die Australiese 
media as 'n rolmodel uitgebeeld is weens sy optimistiese benadering tot die lewe (Lupton, 1999:45).

\subsubsection{Die "soeker na dieper betekenis"}

'n Verdere subtipe van die vigsoorwinnaar wat in die gedigte na vore kom, is die persoon wat dieper betekenis in die siekte soek en dit bewustelik of onbewustelik verpersoonlik (vgl. Stanley, 1999:113). Drie subtipes van die soeker na dieper betekenis word onderskei, naamlik die "soeker na geestelike toevlug", die "sendeling" en die "hemeling".

In drie gedigte manifesteer die soeke na dieper betekenis in die ontvlugting na 'n geestelike wêreld te midde van die lyding. Gedig 4 beeld die vigsslagoffer uit as iemand wat geen hartseer of bekommernis ervaar nie, ten spyte van sy fisieke toestand. Die vryheid van sy siel word gemetaforiseer deur woorde soos skoenlapper, lig en vuur en die beskerming wat sy gees bied teen stigmatisering ("die koue") word gemetaforiseer as 'n kombers:

Sy siel, ' $n$ vlinder in die duisternis

'n Lig wat die donkerte uithou

'n vuur wat die koue blus

Sy gees, 'n kombers wat die koue toevou

Die meeste van die gedigte waarin die "soeker na geestelike toevlug" figureer, dien as gerusstellings om mense met MIV/VIGS te verseker dat hulle nie alleen is nie: daar is 'n kragbron (God), wat te midde van die lyding ondersteuning en rigting gee. Gedig 5 spoor mense met MIV/VIGS aan met die woorde:

ons moenie dat dit ons onderkry

want God se hulp is altyd naby

Nog 'n goeie voorbeeld van so 'n gerusstellingsgedig is no. 20. Elke strofe eindig met die reël: Sien jy hom nog op die pad? Die gedig kulmineer in die volgende strofe:

Alle hoop kom van die Here

En ons weet verseker dat

God woon in gebroke harte

Hy alleen lei op die pad.

In agt gedigte word die MIV-positiewe persoon voorgestel as 'n soeker na dieper betekenis en word die siekte (VIGS) gekonstrueer as 'n instrument wat die geïnfekteerde persoon bewus maak van 'n hoër mag en hom/haar as 'n soort "sendeling" laat optree (kyk Stanley, 1999:113). In gedigte 2 en 13 dien hierdie verwysings 
daartoe om diskoerse van verdoemenis om te keer na diskoerse van vermanings deur God:

Moet ons oorlog teen die sonde verklaar?

Moontlik word ons lewens dan gespaar

Het God hierdie vreemde plaag gestuur

Om ons te waarsku teen die vuur? (gedig 2).

Wat is die doel van hierdie kwaal?

Is dit om ons sondes te vergeld?

Die virus word deur 'n sondige lewe uitgedeel

'n Manier hoe die Here ons tugtig.

Moenie jou kans op 'n lang lewe verspeel

En jou aan sondes verlustig! (gedig 13).

In hierdie tipe transformasieretoriek word MIV beskou as 'n oproep van God om wakker te word en selfvernietigende houdings en gedrag te laat vaar. Dit word 'n morele strategie om sin te maak uit die siekte en om die betekenis daarvan te her-onderhandel. Hierdie getuienis strook met die bevindings van Stanley (1999) oor die morele strategieë wat middelklas wit vroue met MIV gebruik om 'n positiewe selfidentiteit te konstrueer. Dié vroue verklaar byvoorbeeld dat MIV hulle hul roeping in die lewe laat besef het, dat dit tot verlossing van sonde gelei het, of dat dit hulle in staat gestel het om ander te waarsku teen riskante praktyke. Op hierdie manier word die siekte gerekonstrueer as 'n geskenk van God wat mense in staat stel om hulle morele identiteite te reklameer.

'n Derde subtipe van die persoon wat na dieper betekenis soek, is die "hemeling". Die "hemeling" is die persoon wat nie bang is vir die dood nie en wat verlang na die hiernamaals. In gedig 4 besing die outeur die vryheid van die vigsslagoffer (sy vriend) se siel ten spyte van sy gebondenheid aan die siekte. Op sy sterfbed verseker die outeur sy vriend dat hulle weer sal ontmoet, heel moontlik in die lewe ná die dood. In gedig 14 stel die jong digter homself (as denkbeeldige vigslyer) gerus met die woorde: "Net een nag dan's ek in die hemel"; en in gedig 17 word die baba wat met MIV gebore word, gerusgestel met "die hemel wag vir haar onskuldige lyfie".

Die konstruksie van hierdie subtipes is gebaseer op die antieke Christelike narratief (Freccero, 1986) waarin fases voorkom soos 'n lewe van sonde, sondebesef en die ontwaking tot 'n nuwe lewe. Tog herinner hierdie konstruksie ook sterk aan die soort fatalistiese en valse retoriek waarteen Paulus in Romeine 6:1 waarsku, naamlik dat die doen van sonde 'n voorvereiste is vir die ontvangs van genade. 


\section{Gevolgtrekking}

Hoewel dit onrealisties is om te dink dat stigmatisering van mense met MIV/VIGS volledig uit die weg geruim sal kan word, is daar genoegsame bewyse in die literatuur dat dit verminder kan word deur 'n verskeidenheid intervensiestrategieë. 'n Voorwaarde hiervoor is egter dat stigmaversterkende en ook stigmareduserende faktore geïdentifiseer moet word (Brown et al., 2001:16).

Die belangrikste negatiewe response op stigma, wat uit die gedigtekorpus na vore gekom het, is die sekondêre belewing van selfstigmatisering, wat aanleiding gee tot emosies soos vrees, angs, depressie en wanhoop. Die response konstrueer die emosionele en geestelike sy van die "slagoffer"-argetipe. Die groep tieners wat aan die woord is in die gedigte, gee nie voldoende blyke dat hulle die etiese beginsel van goed doen en nie leed aandoen nie geïnternaliseer het nie en dat hulle ingevolge die liefdesgebod ook die self moet liefhê nie.

Die mees prominente positiewe teendiskoers wat egter in die gedigte aangetref word, is dié wat 'n dieper betekenis in MIVbesmetting soek en wat die siekte op een of ander wyse vergeestelik. Hoewel 'n mens hierdie tipe teendiskoers as 'n positiewe reaksie kan beskou, lê die gevaar daarin dat die Christelike evangelie vir tieners en adolessente 'n soort ontvlugtingsroete of selfregverdigingsinstrument kan word, wat uiteindelik teen etiese en morele norme indruis.

My voorstel op grond van bogenoemde data-analise en -interpretasie is dat stigmareduserende intervensies wat op wit SuidAfrikaanse tieners gerig is, die volgende drie komponente moet bevat - komponente wat met Christelik-etiese beginsels strook, naamlik:

- Respek vir die outonomie van ander:

- 'n liefdevolle gesindheid teenoor vigslyers, en

- sowel morele as fisieke ondersteuning

- Goed doen (nie leed aandoen nie):

- weerhouding van skinderpraatjies oor mense met MIV/VIGS en 'n "sieklike" doodsvoyeurisme

- aanvaarding van verantwoordelikheid vir die eie fisieke en emosionele welstand 


\section{- Geregtigheid:}

- aktiewe bevegting van diskriminasie teen mense met MIV of VIGS

- 'n weerhouding van blaamlegging op "ander" sosiale en kulturele groepe (simboliese stigma)

Tieners moet ook bewus gemaak word van die gevare van vergeesteliking van die siekte. Die boodskappe wat in hierdie verband aan hulle oorgedra moet word, is dat MIVIVIGS nie God se straf op individuele of kollektiewe sonde is nie; dat die siekte nie doodeenvoudig 'n oproep tot bekering (wake-up call) is nie; en dat mense met MIVIVIGS nie aan fisieke en emosionele pyn kan ontkom deur hulle gedagtes slegs op die geestelike te rig nie of in hulle gedagtewêreld na die hiernamaals te ontvlug nie.

\section{Geraadpleegde bronne}

AGGLETON, P. 2000. Comparative analysis: research studies from India and Uganda. http://www.unaids.org/publications/documents [15 March 2004].

AGGLETON, P. \& PARKER, R. 2002. A conceptual framework and basis for action: HIVIAIDS stigma and discrimination. http://www.unaids.org/ publications/ documents/human/index.htm [15 April 2004].

BABBIE, E. \& MOUTON, J. 2002. The practice of social research. 2nd ed. Oxford: Oxford University Press.

BROWN, L., TRUJILLO, L. \& MACINTYRE, K. 2001. Interventions to Reduce HIVIAIDS Stigma: What Have We Learned? New York: Population Council. http://www.popcouncil.org/pdfs/horizons/litrvwstigdisc.pdf [14 Des. 2003].

CRIMP, D. 1992. Portraits of people with AIDS. (In Grossberg, L., Nelson, C. \& Treichler, P., eds. Cultural Studies. New York: Routledge. p. 117-133.)

DOVIDIO, J.R., MAJOR, B. \& CROCKER, J. 2000. Stigma: Introduction and overview. (In Heatherton, T.F., Kleck, R.E., Hebl, M.R. \& Hull, J.C. The Social Psychology of Stigma. Londen/New York: Guilford. p. 1-28.)

FAIRCLOUGH, N. 1992. Language and social change. Oxford: Blackwell.

FRECCERO, J. 1986. Autobiography and narrative. (In Heller, T.C., Sosna, M. \& Wellbery, D.E., eds. Reconstrucing individualism. Autonomy, individuality, and the self in Western thought. Stanford: Stanford University Press. p. 1629.)

GEVISSER, M. 1995. AIDS and the media. AIDS Bulletin, 4(1):6-9.

GOLEMAN, D. 1996. Emotional intelligence. Londen: Bloomsbury.

HEREK, G.M. 2002. Thinking about AIDS and stigma: a psychologist's perspective. Journal of Law, Medicine and Ethics, 30:594-607.

HEREK, G.M. \& CAPITANIO, J.P. 1999. AIDS stigma and sexual prejudice. http://psychology.ucdavis.edu/rainbow/html/bibliography.html [25 Jul. 2004].

HEREK, G.M., CAPITANIO, J.P. \& WIDAMAN, K.F. 2002. HIV-related stigma and knowledge in the United States: prevalence and trends, 1991-1999. http://psychology.ucdavis.edu/rainbow/html/bibliography.html [15 March 2004]. 
JACOBY, A. 1994. Felt versus enacted stigma, a concept revisited. Social Science and Medicine, 38:269-274.

JENNINGS, R., MALAUDZI, J., EVERATT, D., RICHTER, M. \& HEYWOOD, M. 2002. Discrimination \& HIVIAIDS. http://www.alp.org.za [15 March 2004].

JUHASZ, A. 1990. The contained threat: women in mainstream AIDS documentary. Journal of Sex Research, 27(1):25-46.

KAVAR, L.F. 1988. Pastoral ministry in the AIDS era. Wayzata: Woodland.

LOVELIFE 2000. Hot prospects, cold facts. Portrait of young South Africa. LoveLive: Johannesburg.

LUPTON, D. 1999. Archetypes of infection: people with HIVIAIDS in the Australian press in the mid 1990s. Sociology of Health \& IIIness, 21(1):3752.

MARSHALL, P.A. \& O'KEEFE, P. 1994. Medical students' first-person narratives of a patient's story of AIDS. Social Science and Medicine, 40(1):67-76.

MSNBC NEWS. 2004. Abandoned AIDS orphans struggle sith stigma. http://msnbc.com/id/6707434 [26 Jan. 2005].

NATIONAL INSTITUTE OF MENTAL HEALTH (NIMH) RESEARCH WORKSHOP. AIDS and Stigma: A conceptual framework and research update. http://psychology.ucdavis.edu/rainbow/html/aids.html [25 Jul. 2004].

NEWS24.COM. 2003. Search results for Edwin Cameron. http://www.news24. com/ News24/quickSearch/1,4366,2-_1168946,00.html [18 Nov. 2003].

NEWS24.COM. 2003. Search results for Nkosi Johnson. http://www.news24. com/News24/quickSearch/1,4366,2-7,00.html [18 Nov. 2003].

PARKER, R. \& AGGLETON, P. 2002. HIVIAIDS-related stigma and discrimination: A conceptual framework and an agenda for action. http://www.popcouncil.org/pdfs/horizons/sdcncptlfrmwrk.pdf [21 Feb. 2003].

PATERSON, G. s.j. Church, AIDS \& stigma. http://www.e-allianace.ch/media/ media-3859.pdf [26 Jan. 2005]

POCOCK, J.W. 2003. HIVIAIDS and its impact on the church and community in South Africa. Pretoria: University of Pretoria. (Unpublished masters thesis.)

SACKS, V. 1996. Women and AIDS: an analysis of media misrepresentations. Social Science and Medicine, 43(1):59-73.

STANLEY, L.D. 1999. Transforming AIDS: The moral management of stigmatized identity. Anthropology \& Medicine, 6(1):103-120.

STEIN, J. 2001. HIVIAIDS and the media. A literature review. Johannesburg: Centre for AIDS Development, Research and Evaluation (CADRE). (3 April 2004).

STEIN, J. 2003. Tackling stigma through treatment and advocacy. AIDS Bulletin, 12(1). http://www.mrc.ac.za/aids/april(2003)/editorial.htm [3 April 2004].

STRYDOM, H. \& VENTER, L. 2002. Sampling and sampling methods. (In Strydom, H., Fouche, C.B. \& Delport, C.S.L., eds. Research at grass roots. 2nd ed. Pretoria: Van Schaik. p. 179-209.)

UNAIDS. 2002. An overview of HIVIAIDS-related stigma and discrimination. http://www.unaids.org/fact_sheets/files/FSstigma_en.html [24 Des. 2002].

VAN DYK, A. 2001. Traditional African beliefs and customs: Implications for AIDS education and prevention in Africa. S.A. Journal of Psychology, 31(2):60-66. 


\section{Kernbegrippe:}

Christelike etiek MIVIVIGS

selfstigmatisering

stigma en destigmatisering

vigsnarratiewe

\section{Key concepts:}

aids narratives

Christian ethics

HIVIAIDS

self-stigmatisation

stigma and destigmatisation 